\title{
CORRESPONDENCE
}

\section{IRITIS IN FOWLS}

To the Editors of THE BRITISH JOURNAL OF OPHTHALMOLOGY

DEAR SIRS,-I read with great interest in your Journal the paper on iritis in fowls by McDonagh and Wolft (Vol. XXIII, p. 659). May I add a few remarks concerning the question.

Fowl paralysis was described by J. Marek, Emeritus Professor at the Veterinary High School, Budapest, in 1907. He was able to separate the disease from the beri-beri type of paralysis. This morbid picture was observed for the first time in three Orpingtons and one Langham. His histological investigations have shown the thickening of nerves and plexi. In 1929 the disease was reported in English breeds by Galloway.

In 1932 Warrack and Dalling have pointed out the common symptom of iritis. The most important work on fowl paralysis is that of Seager, director of Poultry Pathological Research Laboratory, Goring, who gave full description of the clinical manifestations and aetiology of the disease.

An admirable account of ocular symptoms was given by Morax and asscciates in 1934. The histological findings are quite similar to those of McDonagh and Wolff; chronic iridocyclitis, which gives rise to secondary changes (cataract). Corneal oedema was noted. Resemblance to chronic human infections (syphilis, tuberculosis) is emphasized. The term used for "white eyes" is yeux opaques or perlés.

It must be borne in mind that blindness occurring in this disease may be observed in chickens without any external pathology. In this case changes in the optic pathways, especially chiasma, have to be suspected, similar to those of peripheral nerves, vagus, splanchnic nerve, perivascular infiltration, etc. As to the aetiology, the present view generally accepted is that fowl paralysis is caused by filterable organotropic virus. The same may be said concerning optic changes.

$$
\text { I am, Sirs, }
$$

Yours very truly,

STEPHEN DE GRósz, M.D., Assistant at the University Eye Clinic, Budapest, Hungary.

BUdAPEST,

November 1, 1939.

\section{REFERENCES}

- MAREK, J.-Deutch Tierarzte, Woch., Vol. XV, p. 417, 1907.

MoraX, Truche, Vida-Ann. d'Ocul. Vol. CLXXI, p. 383, 1937. 